\title{
Terminology Evolution and Translation: Specificity of Referent \& User's Epistemic Continuum Exemplified in Islamic Terms
}

\author{
Omar A. S. Al-Shabab (Correspondence author) \\ King Abdullah Institute for Translation and Arabization, Imam University \\ 225, Anas St, Al-Malqa, Riyadh 13524, Saudi Arabia \\ E-mail: osalshabab@gmail.com \\ Farida H. Baka \\ King Abdullah Institute for Translation and Arabization, Imam University \\ 225, Anas St, Al-Malqa, Riyadh 13524, Saudi Arabia \\ E-mail: fhbaks@gmail.com
}

Received: 23-05-2015

Published: 01-01-2016
Accepted: 16-09-2015

doi:10.7575/aiac.ijalel.v.5n.1p.94
Advance Access Published: October 2015

URL: http://dx.doi.org/10.7575/aiac.ijalel.v.5n.1p.94

\begin{abstract}
In the dynamics of environmental context, the referent of a linguistic sign changes, but the sign persists as a verbal symbol. Since a technical term strictly evokes one referent, it may lack in specificity due to the ever-changing reality, resulting in homonymy, overlap, and a semantic continuum based on designating by necessity. In addition to the elements of reference theory, the criteria for technical terms postulate the user, whose authority and responsibility are necessary for the term to function as a specific designator. The centrality of the user, translator or otherwise, has hermeneutic and linguistic implications for the evolution of terminology, because it stipulates that terminological meaning and usage are dependent on the user's conscious knowledge, a condition that leads to the recognition of a user epistemic continuum parallel to the semantic necessity continuum. Ideally, a term should be universally specific in reference, and its user should be epistemologically empowered and ethically responsible.
\end{abstract}

Keyword: Terminology, technical terms, Translation, Islamic terminology, semantic continuum

\section{Introduction: Use and Need for Terminology}

The need for communication forced humans in the past to develop a tool whose absence would make our life difficult to imagine, and make mere thinking, development and even contemplation impossible; that tool is language. The developments in language to satisfy and refine meaning in order to refer to what is meant and not anything else, is behind the rise of the theory of naming which takes the fundamental function of language to be giving names to all objects, and later to cognitive concepts. It is the theory promoted by Kripke (1972) in his Naming and Necessity, which holds naming to be the cornerstone for arguing for meaning by necessity, i.e. the word can refer to (and mean) one concrete (signified) entity, or concept and not anything else. Though this theory has its critics, it upholds the necessity condition, which is relevant to the discussion of technical terms as will be shown later.

The refinement of linguistic documents on historical events enables people to transmit their thoughts and beliefs to subsequent generations. The areas whose control demanded greater accuracy and verbal expression included thoughts, laws and universal precepts. They are documented in many forms including religious scrolls and books. Additionally, progress and thought led to refining and specifying linguistic meaning, of which giving a specific meaning to words that referred to measurements, coins, and weight as in the case of silver and gold (Wellisch, 1981).

In the philosophy of language, the notion of naming finds its way to discussions of sense and reference (Russell, 1962, 1993; Frege, 1993) and the debate about definition and definiteness (Miller, 1980). The present discussion centers on language and the evident difficulty surrounding making and using technical terms to evoke one and the same entity in one language and in translation. The Stanford Encyclopedia of Philosophy expresses the exclusivity of reference in an account about rigid designators, succinctly: "A rigid designator designates the same object in all possible worlds in which that object exists and never designates anything else. ... Hence, much of the discussion in various sub disciplines of philosophy is explicitly or implicitly framed around the distinction between rigid and non-rigid designators". But in everyday use, this is not attainable with many terms in the fields of humanities, cultural studies and religious texts, a fact which calls for investigating the role of the language user of technical terms in such situations. This leads us to the question about the limits and possible contribution of the theory of sign as used in linguistics to the current discussion of technical terms. 


\section{Literature Review and Theoretical Framework}

In terminology the focus is three-dimensional: allocating one utterance (signifier) for the term, ensuring the uniqueness of the signified (meaning) of the term (referent), and enforcing the currency of the term. At a linguistic level, the three props of the terminology project are the theory of reference, which ensures the elements of technical terms, meaning by necessity. The specificity of reference, first person authority and speaking from disquotation, will ensure authority and responsibility of the term initiator/user. The background of this theoretical apparatus will be reviewed below with the aim of laying proper foundations for the creation and use of terminology in first order discourse and in translation.

The theory of reference which, in our view, can be traced back to Plato's theory of forms (Plato, The Republic), operates by assuming a direct relationship between the verbal element which carries the reference and what is being referred to, the signified, both of which interact to produce the meaning of the linguistic sign (De Saussure, 1916; and Lyons, 1968). The relations among the members of semantic triangle are more complex than the primary explication offered by De Saussure (1916) as a relation between a conventional system of signs and a dynamic interaction between evolution of verbal utterances and non-verbal referents. The classical summary offered by general linguists (cf. Lyons, 1968) has a central focus on the arbitrariness of the relationship between word and referent and on the interaction of these two, to yield the linguistic sign, i.e. meaning. Richards and Ogden who produced their detailed volume The Meaning of Meaning (1923) on the topic more than fifty years earlier than Lyons, put forward an ontological scheme which wedges the theory of linguistic sign between the referent which is realized in the external context and experience, and symbols which realize the conceptual system of thought or psychology. Hence, the external worlds and symbols come to mean what they mean via psychologically processing thought in linguistic context, i.e. situation. The term used in Richards and Ogden's semantic triangle, put in brackets in figure (1) below reveals the three knowledge areas upon which the model rests: symbol for the linguistic system, referent for objects or concepts, and thought for meaning as psychological experience and sensation. They believe that the "analysis of the relation between words and facts is the essential of a theory of meaning" (Richards \& Ogden, 1923, p. 2), and that "symbols and referents,..., are not connected directly" but through thought or the linguistic sign. Accordingly, the proper connection and interpretation of the symbol and its meaning is undertaken with reference to the sign situation which determines the context:

(1)The simplest terminology in which this kind of linkage can be stated is that of signs. Behind all interpretation we have the fact that when part of an external context recurs in experience this part is, through its linkage with a member of some psychological context ... sometimes a sign of the rest of the external context" (Richards \& Ogden, 1923, p. 57)

The context is in turn defined as "a set of entities (things or events) related in a certain way" (ibid. p. 58). Internal and external contexts are further related to the truth of statements, because "we have seen that true and false beliefs are members of the same kinds of psychological contexts, and that they differ only in respect of external contexts" (Richards \& Ogden, 1923, p. 68). In Figure (1), Richard and Ogden's terms appear in brackets and the user's interpretation is included.

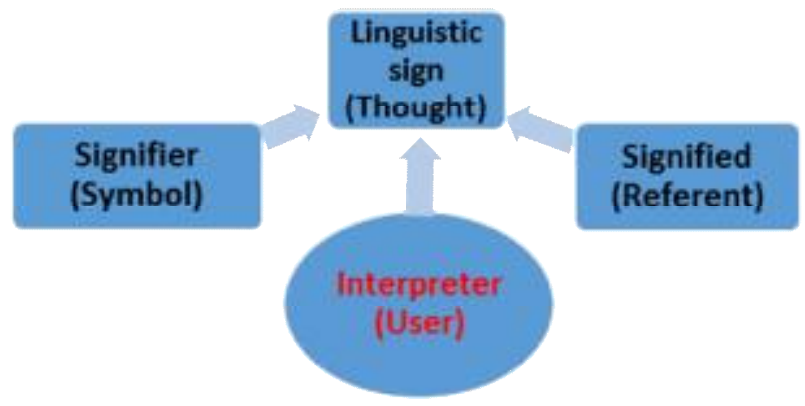

Figure 1. Elements of Reference Theory and the user: the terms in brackets are used

From Richards and Ogden 1923, and the human user is added by the current researchers

Thought is relatable to symbol through "causal relations" (ibid. p. 10), and the acts of "judging, or believing, or thinking of something" lead Richards and Ogden to inquire about the "something" which "is related to the mental event which is our judging, our believing, our thinking” (Richards \& Ogden, 1923, p. 51). The psychological dimension is explained in terms of repetition holding "stimulus" to "response" (ibid. p. 53) and mental processes and "awareness" (ibid. p. 53). Thus, the study of symbolism and "its Influence on thought" (ibid. p. 9), the centrality of context (ibid. p. 10) and using experience in making sense of linguistic signs, all play a role in our life (p. 51). But most important is the ontological implications of establishing relationships and boundaries among disciplines, language, external reality and psychology, which is Richards and Ogden's theory of human communication. One important methodological observation of this theory states that "a theory of Definition must follow, not precede a theory of Sign" how it is "little realized how large a place is taken in abstract thought and in practical affairs by sign situations" (Richards \& Ogden, 1923, p. 19). 
Two vital elements of the sign theory as presented above can serve the debate concerning terminology, the sign situation and its content, and the precedence of this theory to a "theory of Definition", though what is needed for a technical term to fulfill its terminological function is definiteness and not merely a definition. An insight that may assist definiteness is that one symbol can refer to a number of referents, a position that Richards and Ogden do not elaborate on but indirectly discuss in case of dual and multiple context where a specific symbol or experience may evoke more than one "character", i.e. a mental event or different aspects of the event (producing a flame is their example, Richards \& Ogden, 1923, p. 52).

The second theoretical dimension which relates to terminology is the notion of necessity or meaning by necessity, a case in which an utterance or a name means what it means by necessity rather than by reference or qualification, mainly because the descriptors per se inherent in the name are enough to evoke the meaning. Necessity is not easy to obtain out of context, and when the context is extended to background information (Author, forthcoming) and modification (Rosenberge, 1994), the necessity condition is flouted. The terminological turn, however, operates on the specificity of the referent and hence, the uniqueness of reference or meaning of the term. Kripke's rigid descriptors (Kripke, 1972) may save the day in some cases, but in many cases where homonymous words refer to a good number of terms, i.e. different referents, neither necessity nor specificity would help to confine the meaning of a name.

The third theoretical issue that pertains to creating and utilizing a term is the knowledge and authority of the term initiator and/or user. A soft position on the notion of "speaking from disquotation" may help determine the authority of the speaker and authenticity of the meaning of the term in question. Here, Davidson's "first person authority" (Davidson, 2006) would empower the term user, although one has to be wary of indulging in self-illusion and circularity of meaning and ultimately tautology resulting from internalism. Now, whether the speaker is the best judge about the truth or real meaning of his statements is far from having been resolved; but taking the individual user's knowledge into account is necessary. This epistemic dimension which justifies the user's authority and responsibility, operates in what we have termed "first person domain" (FPD) within which the mental lexicon and various processes of interpretation interact (Author, 2012a \& forthcoming). Therefore, the triangle of reference theory needs to incorporate the user's epistemic dimension to formalize the epistemic background against which a term is coined and/or used (cf. Searle's felicity conditions which specify the circumstances and status of the utterer, and Grice's cooperative principle). Therefore, in addition to linguistic (system) signification, two aspects of terminology need to be satisfied; first rigid designation of symbol/designator, and second the epistemics and responsibility of the term initiator/user. The present elaboration on the sign theory, however, should not be understood as presenting it as the ultimate theory of semantics or language. In other words, handy as it is in the discussion of terminology and definition, it cannot substitute theories of speech acts, relevance (Sperber \& Wilson, 1995), or text hermeneutics.

\section{Technical Terms: Elements, Criteria Definition and types}

The discussion in the above section has outlined the elements and theoretical apparatus upon which the criteria for establishing and suing a technical term rests. As for the elements in favor of terminology-specific requirements, Kripke's notion of necessity and rigid designation can serve in labeling the elements of technical terms as Figure (2) shows:

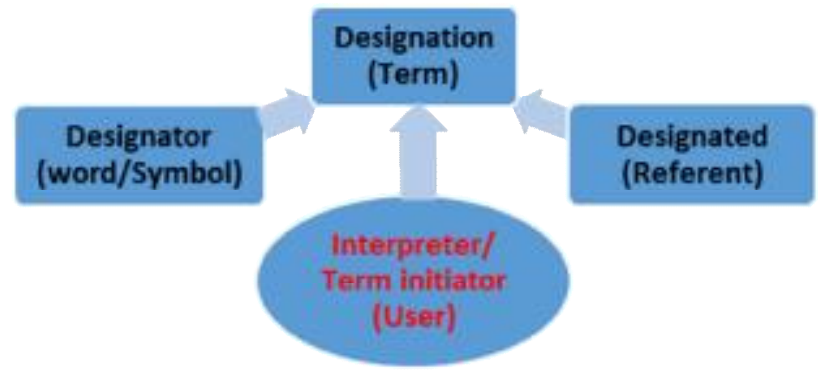

Figure 2. The Elements of a Technical term employing the triangle of Reference Theory and the User

The term as a rigid designator has the function of restricting the referent, context, to one referent in all possible worlds, i.e. one specific meaning. The textual context in actual use will vary but what is strictly designated is one in all possible contexts. Linguistic necessity and specificity of designation need not conflict with the fact that a symbol and a referent are not directly related, because the arbitrariness of the basic relation between them operates at a higher theoretical level of abstraction, while the specific designation is empowered and restricted in order to serve in well-defined semantic function. Thus, the term initiator or user arbitrarily links the verbal sign to a referent at a theoretical level, and at the same time endows the sign with specific, strict designation which should mean no more and no less than the designated object or concept.

The criteria of initiating a new technical term and later using it in actual discourse are suggested for both coining new terms, and analyzing existing ones and their use and user. The criteria below are assumed to be satisfied in the ideal case but may not be all activated in every case a term is initiated or used: 
1. Environment: The socio-linguistic environment for initiating/using the term is a natural requirement for initiating and using it, since the term emerges and is used to satisfy the need of a given discourse community which has specific linguistic culture.

2. User: The term user which covers initiator, or translator, should be qualified, since a term is born in a given environment and a given discourse community that requires the user to have mastery of the field which evokes the need for the term. A given term may develop naturally to be used by non-scholars, but the discussion or study which authorizes and naturalizes the term is carried out in professional and/or academic context. The user, and even the translator, of technical terminology may not be adequately qualified, which makes his verbalization of the term reflect partial knowledge or repetition and no more.

3. Authority: The user's epistemic authority refers to an aspect of terminology requiring that the term initiator/user has the power of knowing what the term means in a specific domain for a specific purpose. Epistemic authority allows the speaker, whether initiating or using the term, to be in a "privileged position" (Davidson, 2006) to enjoy special knowledge about his use of the term, not shared by non-specialists.

4. Integrity and responsibility: The speaker says what he/she says as a primary, not quoted, text with full responsibility for the truth of the meaning of his/her statements. Disquotation amounts to self-ascription and evokes the debate about externalism versus internalism (Author, 2012b), but in the present context it can serve in assigning the responsibility for the meaning of the term(s) being used to its initiator or user.

5. Designator: This is the utterance (usually one lexical item) as verbal realization which specifically refers to the meaning being designated by the term.

6. Designated: This is the specific object, concept, or event being specified by the designator.

7. Designation: This embodies the meaning or what is being designated by the term as verbal realization. It signifies the meaning that results from the interaction between the designator and the designated. It is a typical operation according to the theory of linguistic sign, in which the referent can be an object, concept, event, action or, in the case of grammar words, a structural function.

8. Specificity: This criterion guarantees the exclusivity of referent, a condition of non-sharing or optimal specificity, which entails that the designator, designated and designation coincide and exclusively specify one entity. In general language, this criterion is referred to as being "exact", in the sense of recalling the referent and nothing else.

9. Necessity: This requires that the designator per se should mean what it means with no modification, qualification or explanation, in a way similar to Kripke's notion of a rigid designator (Kripke, 1972).

Three points of clarification are needed here. Firstly, the above criteria are comprehensive in the sense that they are not found in every case of terminology, but they apply to the ideal case of the first time the term is initiated, or when it is used with full awareness of its meaning and implications. Secondly, meaning by necessity or being a rigid designator, to use Kripke's term, does not conflict with the arbitrariness of the relation between designator and designated, since necessity and arbitrariness function at different levels of linguistic analysis; the first expounds a linguistic theory of sign, while the second is a mere designator of a specific meaning. In brief, in the early stages of its evolutionary preliminary use, language reflected humans' natural habitat of sounds and object, and only after hundreds of thousands of years of evolution, reference to concepts and relations away from natural phenomena was possible. A term designates the meaning assigned to it and nothing else by necessity, just like a proper name according to Kripke (1972). The term's interpretation should be rigidly guided by its referent, since a mere reference to the designated should suffice to evoke the meaning with no addition or modification (cf. Author, 2008).

The above criteria can be classified into four categories each of which functions at a specific level;

1. Criteria One and Two: These two criteria fall outside the linguistic system per se; but still language shapes use, user and environment in which it is used.

2. Criteria Three and Four: These two criteria specify the language user's authority which empowers him to interpret and use the term, and invoke the responsibility of the user's ascribing the term to himself, satisfying the discourse epistemic conditions, and assuming responsibility for his discourse including the truth of his statements. The speaker has the necessary competency, responsibility, authority and consciousness when using a term.

3. Criteria Five, Six and Seven: These criteria belong to the linguistic system proper, and operate within the linguistic theory of sign discussed in (2) above.

4. Criteria Eight and Nine: These criteria belong to meta-theory, because they focus on restricting the referent and consequently the meaning.

The above elements and criteria for initiating and using technical terms enable us to put forward the following operational definition: a technical term is an utterance used in a discourse community to attach a designator to a designated to convey a specific meaning and no other meaning.

Naturally, the discourse community, which is either professional or academic, operates in a well-defined social and epistemic context that secures the retrieval of the referent and the appropriate interpretation of the term.

\subsection{The Origin and Sources of terminology}

Terminology is the legitimate child of abstraction, because it is born within the framework of a new theory, a new school of thought, a new discovery or religion. Islamic terminology, for instance, is part of the last group, since the advent of Islam created an infinite space to be filled by new contents covering practical affairs of social life, death, and 
thereafter. Among the features of Islamic terminology is the openness to a vast potential of thought, reasoning, contemplation, practical affairs and involvement in creating terminology in various fields, which according to Al-Jabri (1993) led to the emergence of new sciences in addition to contributing to old ones. The translator of Islamic literature feeds on this potential of Islamic terms, and theorists in the past and now also use this potential to support their theories. Terms about Quran recitation and legality of inheritance would not be known had they not occurred in the Holy Quran, and terms about the Prophet's sayings (Hadith) were not known before the contribution of the Prophet's sayings scholars to the various aspects of this tradition. The expansion in sharia studies and Islamic culture and Islamic studies, like worship, jurisprudence, commercial transactions, civil society, studies of Islamic communities and countries including the relationship between Islam and the other and, significantly, translating Islamic texts, all present areas open for generating new technical terms. Therefore, the study of Islamic terminology needs to undergo a comprehensive review of current usage, in order to find the appropriate approach to modern usage. This is particularly true if one remembers that old scholars reviewed and reformed terminology by taking real life context into consideration and by endorsing social welfare.

Texts make a rich mine for excavating terms, since the text constitutes the ultimate realization of linguistic use and context, and they serve as an incubator for terminology. Naturally, one finds those who refer to the specialized dictionary to search for the meaning of technical terms. But the dictionary term is originally derived from a text, and hence the authority of the dictionary cannot supersede that of the source and its user, who, out of epistemic prerogative initiates the term in a specific context and uses it in a text or a dictionary. At present, one can easily notice the great number of "specialized" dictionaries on different specializations compiled by non-specialists in the relevant subject domain (Abu-Saleh, 2014). In brief, terms should be initiated or at least formalized by specialists in the field or in the relevant profession, and should be taken from specialized dictionaries prepared by specialists as in the case of glossaries and dictionaries produced by language academies and recognized scholars. The source may be a representative corpus, or it may be a glossary attached to specialized books produced by translators and/or experts in the field. Randomly collected glossaries produced by non-specialists or commercial publishers, which are opaquely ascribed to institutions or publishers fall under the category of obscure and doubtful sources.

\subsection{Making Technical Terms: Method and Evolution}

Terms are characterized by different levels of abstraction, a fact that is observed in their reference to concrete objects, and events, or to theoretical concepts in a wider framework. This entails that the linguistic method employed by professionals and ordinary people on the one hand, and academics on the other, are inherently different. Laymen and professionals create terms that naturally evolve in the course of life or their vocation, just like the creative use of language in everyday life. Researchers and academics, however, resort to their experience in the subject domain and ultimately their epistemic cognitive background, and their knowledge of the linguistic system in addition to inflectional forms such as verbs, nouns, ing-form, en-form, and gerund, or derivational forms such as blending, compounding, and acronyms. In addition, borrowing from other languages, using old existing words in one's language, and coinage are among the common methods of making new terms. One of the major importer of new terminology is translation (see 4 below).

However, the proposal of a new term is one thing and its spread and currency is something else. The initiator's authority, responsibility and epistemics identity enable him/her to suggest and use a given term, but the life cycle of that term depends on external factors beyond the initiator, and even beyond the field within which he/she operates. One main factor in the spread of a certain set of terms is institutional, since learning institutions, language academies supported by political ambitions, work hard to enforce their vision and literally "dictate" their terms which gain currency later (as in the use of measurement units, meter and inch by France and Britain respectively). But the initiation of new terms may overlap, interfering with other existing referents, i.e. concepts using the same symbol. When a word is used to refer to a new construct, the word as a symbol may blur the new referent and consequently abort the new meaning due to incommensurability, i.e. the impossibility to claim that the referent is one and the same as it was initiated by a previous theory (see Kuhn, 1962). Much of Islamic terminology is a case in point, because the context, situation and theoretical apparatus, and not the main issues raised and theorized, reveal a belief system that is appropriate for those circumstances and theoretical elaboration. But reality and the state of knowledge today are far removed from the environment and argumentation relevant to the old term, and thus they call for a revival in terminology and specialized argumentation to speak to the present and avoid ambiguity.

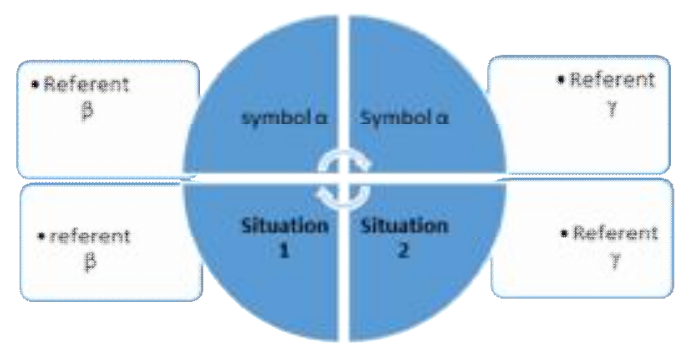

Figure 3. The same symbol persists with different referents and new situations 
The dynamics of reality (situation $1 \& 2$ ) and the static nature of the symbol $(\alpha)$, the verbal behavior, especially when written, has detrimental impact on the meaning of the term, in the sense that the same symbol, word, may refer to more or less referents $(\beta, \gamma, \delta$ etc.) to more or less functions than was intended by the term initiator in the first place, i.e. situation 1 in Figure (3).

But there is another evolutionary continuum which charts the initiation, culmination and then decline of a term. When the term is first introduced, it may be clear and vivid, but with the laps of time and the advancement of change in knowledge and the social and environmental situation, the term can be superseded, modified or overshadowed due to the lack of interest in the field or decline in the state of the art to which the term belongs. Naturally, the term will decline in relevance and use, outlining the life cycle of a term as initiation, culmination, (possible) revival, and finally, decline. Two continuums can be recognized, one showing the overlap or change of meaning due to the discrepancy between the old word (designator) and the new referent (designated), and the changes in the meaning of the term due to natural change in reality which is not registered by change in the term as symbol, leading ultimately to a decline showing a faint blurred meaning. The next section will discuss a third continuum which is not spread along the time continuum, but rather on the synchronic semantic continuum, showing the relevance of the epistemics of the user.

Every language user employs technical terms, but specialized professionals and academics employ them more and know their exact context and meaning. In addition, professionals and academics usually produce new terms. To start with, this observation implies that not all users interact with terminology in the same way, and hence according to the basic epistemic involvement with a set of terms, language users can be classified into five categories, which are relatable to the four groups of criteria suggested above.

1- Pre-conscious user (not aware of a given term or a set of terms)

2- Conscious user (aware of the existence of a given term or a set of term)

3- Experiential learner user

4- Professional/academic user Researcher and identifier

5- Initiator user

In relation to a given term or set of terms, the user's epistemic continuum stretches from zero knowledge to complete knowledge of the term, making the epistemic evolution a natural progress from ignorance to complete mastery. The word conscious is preferred to ignorant, although consciousness is to be understood as conscious of the knowledge of the term and not conscious of matter or the physical world. Progress towards knowledge shows that pre-conscious users of terms are not in a state of not being conscious of the physical world, and that the learning process is a combination of Kolb's (1984) experiential learning cycle and a conscious motivation for self-identification. Environmental and educational input acts as the force behind arousing consciousness and searching for a constructive role and purpose in life whether academic or not. But the individuals who reach the stage of self-identification and start to practice constructing as well as employing a professional and/or academic terminology, those individuals stand a chance to reach the stage of the complete knower of their stock of terms, and thus be empowered by the epistemic prerogative. Accordingly this epistemic evolution which culminates in contributing to the terms in a certain subject domain, is accompanied by self-development, which makes the term user a knowledgeable user, and makes knowledge both human and conscious knowledge.

\begin{tabular}{|c|c|c|c|c|}
\hline $\begin{array}{c}\text { Pre- } \\
\text { conscious } \\
\text { user }\end{array}$ & $\begin{array}{c}\text { Conscious } \\
\text { user }\end{array}$ & $\begin{array}{c}\text { Learner } \\
\text { user }\end{array}$ & $\begin{array}{c}\text { Professional/ } \\
\text { academic } \\
\text { user }\end{array}$ & $\begin{array}{c}\text { Initiator } \\
\text { user }\end{array}$ \\
\hline
\end{tabular}

Figure 4. The User's Epistemic Continuum

Now we can propose two main methods for the construction/initiation of technical terms: the first method is natural, unplanned, made necessary by the environment of work especially in certain professions which use specific jargon, and the second method is conscious, planned method based on the user's epistemic evolution as a learner, searcher, researcher and specialist whose practical or theoretical experience in the subject domain requires the employment or the construction of terminology. First through a learning experience involving successive learning cycles and later through involvement in the development of the theoretical apparatus of his/her subject domain, an academic reaches the stage of complete knowledge of the terms in the relevant field in general and his specific theoretical frame in particular. The terms mastered through learning experience are large in number and inherited from previous theories and practices, but the latter ones tend to be fewer and either refined or initiated by the full-fledged scholar.

\section{Islamic Terms on the Semantic Continuum}

Terminology develops with the mutation typical of new surge in social, economic, academic or political life; the advent of a new religion in Arabia in the early part of the seventh century brought with such a surge in two small towns in Arabia, Makka and Yathreb (known also as Al-Madina Al-Munawarah). Islam created the environment, the events and textual reference, the Quran and later the Prophet's sayings, all of which constitute the bedrock against which Islamic terminology rests. In addition to practical affairs, Islam covers matters of death and after death. Later development of Islamic theology and scholarship extended to cover a wide range of new sciences and terminology to match all of them, terminology which has known many a revival to the present day. Few examples would suffice to make the point about the developments of Islamic terminology over the centuries. 
The first term to be looked at is sheikh, which means an old man, a prominent figure or a chief of a tribe, three meanings of the word which predate the advent of Islam and are still in use in Arabic today. The meaning has evolved over the years in ordinary language to include teachers, professor (used in Algeria), a wise man and a social title (a respectful title of a man, Saudi Arabia). But as an Islamic term, sheikh designates a prominent scholar as in Sheikh Abdulhamid bin Badees, the founder of the Scholars Association in Algeria in the first half of the twentieth century, or Sheikh Al-Azhar, the leader of the Islamic school of Al-Azhar (a below), or a versed Islamic scholar of accredited position and exegesis as in (b). The person who is appointed, by government or by consensus to lead the prayer and to give the ceremony on Friday (c) is also Sheikh, and finally the two prominent compilers of Prophet Muhammad's traditions are also known as Al-Shaykhān, the two Sheikhs, because their work has been put together and accredited as al-SaHīH (the true) narration of the Prophet's traditions.

(2) Sheikh

a) Sheikh Al-Azhar

b) Sheikh Al-Islam (reference to bin Taymiyyah)

c) Sheikh: the prominent person versed in Islam and employed to lead the prayer and give Friday ceremony (Saleh, 2011, p. 216)

d) The two Sheikhs (reference to Al-Bukhari and Muslim, two scholars known for collecting and compiling the authentic Hadith of Prophet Muhammad)

The long history of the Arabic language and Islamic scholarship add to the complexity of the terminological labyrinthine, as the history of the term imam shows.

(3) Imam

a) First, leader, head (Saleh, 2011, p. 96)

b) Leader of collective Muslim prayer

c) Scholar (not necessarily in religious sense)

d) Prominent religious figure

e) One of the twelve Imams of Shi'a Muslims (see http://www.saaid.net/feraq/mthahb/ 1.htm; and see http://mb-soft.com/believe/txw/imams.htm)

f) A title of Al-Hussein son of Ali and Ali himself (see http://www.saaid.net/feraq/mthahb/ 1.htm; http://mb-soft.com/believe/txw/imams.htm)

g) Reference to Prophets Ibrahim and Moses (Quran: Sura 2, verse 124, Sura 11, verse 17, Sura 46, verse 12)

h) Reference to Prophet Muhammad

The basic cognate designates being first leading (3.a), and this defines the technical sense of (3.b) leading the collective prayer. In (3.c) the notion of a person of notable respect in Islamic studies is central, but sometimes a widely learned person, as Imam Muhammad Abdo (an Egyptian scholar of the nineteenth century). Imam is also used to mean a prominent religious scholar as in the reference to Imam Muhammad Ibn Saud, whose name is given to a University in Riyadh (3.d), Saudi Arabia. The word (3.e) has a special significance for Shi'a Muslims who hold that there are eleven Imams and that the twelfth will appear in the future (see http:// www.saaid.net/feraq/mthahb/ 1.htm), and this is closely related to (3.f) where the word imam refers to Al-Hussein son of Ali Ibn Abu Taleb (Ibid.). One also finds, especially in literary texts, that the word imam is used in reference to Prophet Muhammad. It can easily be seen that there is some overlap in the meaning of Imam and Sheikh, and the complexity arises from the long history of the term i.e. symbol, although each technical meaning has a history of its own and, in some usage, a theological sanctity that is not shared with other meanings. If the semantic evolution of the word is traced, one can recognize a semantic continuum through which the term progresses in specificity keeping a nucleus of being the first, a leader, as Figure (3) shows:

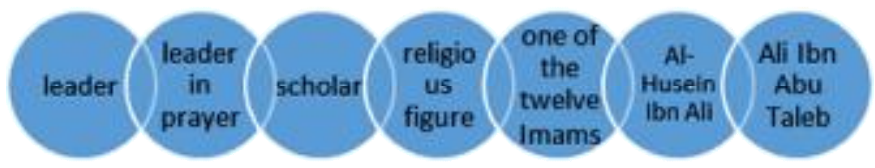

Figure 5. The Semantic continuum of the word Imam

With each term the technical factor can be plotted on a scale as shown in classifying technological and computer terms according to the category of the subject domain and the level of tech factor (see TtechTerms.com). But from the viewpoint of all users of the word, it can be seen that some would hardly know any of the specific meanings in (5) above, while other users are not only knowledgeable about the meanings, but they at the same time maintain strong views as why one term is correct or should be modified or has no validity at all. This reinforces the epistemic continuum (Figure 3), that makes it possible to suggest the presence of an epistemic semantic continuum along which users spread from the zero knowledgeable to the most knowledgeable, and between the two ends, users are graded according to their epistemic stage ${ }^{i}$ vis-s-vis a given term (see Figure 4). 


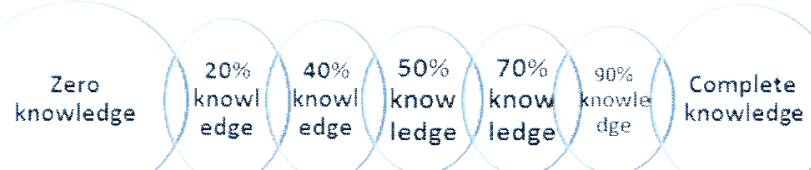

Figure 6. The Epistemic continuum of knowing a term.

Now one special difficulty with using Islamic terms against the rich ontological reservoir and history of Islamic terminology becomes clear when one takes into account the changing dynamics of reality and the static nature of the written word, a situation aggravated by the fact that the immediate context and the wider environment which produced the relevant set of terms in the past have changed and in many cases are not relevant to the real world today. This has on many an occasion led to resistance, and even rejection and confrontation, of new discourse and reform of language and terminology. Surely, new epistemic content of the current environment cannot be easily compromised with the old terminology and terminological apparatus. The way to progress can emerge only through adopting a discourse and terminology that address present day context, and only by scholars who have full knowledge of the implication and impact of terminological reform and the best methods of achieving this revival at the hands of experts and specialists working from modern ontology, and not leaving the field for those working with the history of Islamic terminology and old approaches to knowledge.

\section{Terminology and Translation: Challenges and Opportunities}

Approaching the translation of a technical term, the translator as term user should be aware of the knowledge-base, the knowledge system and the knowledge level, and this enables him to realize the knowledge gap which may exist between the required epistemic and the current state of knowledge. Now, a wide knowledge gap can be used to measure the greater effort needed and to predict a wider margin for errors in the translation. The interpretive process goes through epistemic processing of information in SL to contextualize the term in the ST before processing semantic transportation and elaboration of commensurability, i.e. translation is based on epistemic contextualization in preformulation of the translated text (TT) (Author, forthcoming). Translation studies the theoretical as well as the wider perspective related to translation within the framework of language planning, which will be briefly touched on below.

The place and time for a panoramic review of translation from and into Arabic is not here; such a review of that history is made difficult due to the missing of a large part of the evidence and scattering of the remaining parts in countries that have secured control over access to the literature. The two-way trade in the last involving recent Arabic translation history can be traced to small-scale projects in the eighteenth century such as translating church service into Arabic in 1720s (see Ross, 1979) and translating Napoleonic declarations addressed to Egyptians in 1798 (Al-Gabarti, 2009). The nineteenth century witnessed the real launch of Arabization in Egypt (Tajer, 1945) and translation in Tunisia (Mawada, 1986). In the twentieth century translation and Arabization moved to the public sphere to become a political issue, taking away this linguistic phenomenon from the professional practice and academic study to the national level of grand projects whose rise and fall depended on the politics of the day (Numan, 1981, Al-Sayadi 1982, and Badawi, ND). Before moving to examine the examples of translating Islamic terms, translating terminology into Arabic, Arabization, will be undertaken. When foreign words indicating new inventions arrive in the public domain, they are used as loan words which may later be Arabized, as in the case of telegram, telephone, radio, drama, train, bus, inch and meter. Even when the Arabic term has established itself as in the case of masraHiyyah (drama), hātif(telephone), qiTār (train), $b \bar{u} S a h$ (inch) and Häfilah (bus), the foreign loan term remains in use, either for a restricted context as drama in reference to TV drama and art, or for prestige by the young generation. ${ }^{\mathrm{ii}}$ One permanent feature of Arabization has been seen in the emergence of more than one Arabic term for the same English or French one. Thus, a car is called 'arabiyah in Egypt and sayyarah in Syria and the Arabian Gulf countries. The Foreign Ministry is wazārat alkhärijiyya in Syria, Egypt and the Gulf countries, but wazärat ashsh'ün alkhärijiyya (translation from French) in Algeria, and the same applies to the Ministry of Agriculture which is either wazārat azzirā'a or wazārat alfiläHa. This is a natural development in the process of labeling, since in English one finds the Foreign Office in Britain is the Foreign Ministry in the USA and Le Ministère des Affaires Etrangères in France. Sociolinguistic and historical reasons play a part in the diversity of translated terminology, but deliberate language planning and policy, even rivalry, are behind much of the chaos as research has indicated (Al-Sayadi, 1982).

Moving to translation from Arabic, one moves to a completely different picture in which the main beneficiaries are nonArabs and native speakers of languages other than Arabic. Arabic literature and Arabic-Islamic science came low on the scale of priority, compared with translating Islamic works and naturally Islamic terms (Pym, 1994 \& 1995). This has not always been the case, since the request to participate in the translation of the Quran into Latin was considered by Robert of Ketton, one of two main translators, to be an unwanted distraction from working on the translations of books on mathematics and astronomy, a distraction for which the bishop of Gluny had to pay in gold (Pym, 1995). Up to the second decade of the twentieth century, most of the translators of the Holy Quran into European languages were carried out by non-Muslims, and until recently by non-Arabs. ${ }^{\text {iii }}$

In Asia, the situation is different, since Muslims there wanted to read the text in their own language, which resulted in a long history of translating the Quran into Persian, Urdu and Indonesian. But since the 1950s, Quran translation has known a surge in the number of languages and translations into individual languages, for many reasons, some of which 
are commercial or personal. Oxford University Press, for instance, has published more than one translation including Palmer's in the nineteenth century and Halim in the twenty-first century. Thomas Irving an American convert to Islam participated with Ahsan in a translation which was published by the Islamic Foundation in London (1979), but in America he published a translation of his own. The most devoted publisher and distributor of the translation of the "meaning" of the Holy Quran is King Fahd Glorious Quran Printing Complex in Al-Madinah, Saudi Arabia. Now theological and linguistic reasons have been behind much of the controversies and differences one finds in the recent transplantations of the Holy Quran. In the nineteenth century Ahmadiyya sect published their own translation (Idara Dawat, 1997), and Marracci, the Bishop of Badwa spent forty years in preparing his Latin translation of the Quran and his commentary on it, adopting an overt vocal position against Islam and most hostile towards its Prophet. ${ }^{\text {iv }}$ His Refutati AlQurani was doomed to fail as a refutation of the Muslim faith and creed, but his translation gave a complete accurate parallel Latin, which has influenced almost all Europe translations after him (see Author, 2000, 2001, 2003, 2008, $1012 \mathrm{~b}$ and forthcoming).

As seen in section (6) above, Islamic terminology makes one of the most hotly debated issues in the translation of the Quran and other Islamic texts including Prophet Muhammad's sayings. The reasons are very many and need sociocultural investigation, but few examples may shed light on the complexity of the scene. The first issue of debate concerns the basic question whether the Quran should be translated. Historically, there is a position that the Quran cannot and should not be translated as argued by Al-Safi, who wrote a book to explain that translation is bid'ah, a newly practiced innovation, whether the translation aims at reproducing the meanings, the utterances or any aspect of the text (Al-Safi, 1991). But after Abdullah Yusif Ali's translation (1934), which was repeatedly reprinted and later modified and published as the official version of King Fad Printing Complex, many translations into European languages by Muslims and non-Muslims have been published.

The controversial renderings are very many, the first and most indicative is the rendering the word Allah which in Arabic refers to Al-mighty God. The most obvious objection to the word God (English), Gott (German), Dieu (French), or deus (Latin), seems to stem from a valid desire to distinguish the Muslim deity from the deity worshiped by ancient Egyptians, ancient Greeks, and Christians who all do not believe in one God Who has neither a parallel or similar entity, nor a son, a precedence or a partner of any sort, being the first with no beginning and the last with no ending. To my knowledge, the solution of using the Arabic word Allah in the translated text appeared in Fatma-Zaida (1861), and later this term was advocated by the translations of the "meanings" of the Holy Quran into a good number of languages by King Fahd Complex, to become a beacon for translations that subscribe to this stand, sometimes giving linguistic reasons for not adopting the target language possible words. This practice, or translation, is not without drawbacks, since for a non-Muslim it may evoke the idea that Islam has a special deity specific to it. Borrowing foreign words in translation is not new, but the practice has inherent communication problems. Firstly, the reader of the translation is not better informed when the source language word appears in the translated text, but a subscript is necessary to explain and guide the reader to the meaning of the borrowed term. But a more serious problem would be faced if the translated text is swarmed with borrowing. The overuse of borrowing will lead to discourse practiced by those whose language manifests constant code-switching. In some television programs this type of hybrid language primarily conveys the content regardless of the structure.

Leaving the name referring to God and how to approach this sensitive issue in translation, one finds hundreds of terms which pose serious doubts about the very possibility of achieving an accurate "equivalence", and borrowing is employed by many translators for different reasons. One example in point is the rendering of the word zakāh, nearest to alms giving, but still sometimes the Arabic term is borrowed. The same is true to Islamic terms like Tawāf (going round Kabba seven times, Sa i (walking seven times between two sites near Kabba called Safā and marwah), Haj (pilgrimage) and $w u D \bar{u}^{\prime}$ (ablution) (for the meaning of these words, see Saleh, 2011). It is true that translational commensurability is, at best, an approximation (Author, 2010), but even the borrowed term will not function semantically speaking as it does in the source language, Arabic, although its pronunciation and use in the target language seems to convey its meaning. In light of this analysis, if a translation is to be given of these terms, it can be a choice of the best approximation, and then the goodwill is shown in respecting the translation by adhering to it by Muslims scholars and institutions, for better communicating the purpose and eventual welfare of all users of the translation.

\section{Conclusion}

The relation between symbol and referent has been recognized and explained in various ways (Russell 1962, 1993 \& Frege 1993). Notably, the basic linguistic approach to the theory of sign as developed by Saussure assumes that the relationship between a sign and referent is essentially arbitrary, a principle which has an explanatory power demonstrated, according to Duan (2012), in two areas "arbitrariness in relation to the creativity of language and arbitrariness in relation to semantic gaps and exceptions in linguistic regularity" (Duan, 2012, p. 57). From the information processing angle, Guarino (1992) postulates that the entity and attribute in definitions within the frame of artificial language are expressed in formal (logical) relations; but "this kind of situation is frequent in natural language" (Guarino, 1992, p. 15). Hence, his position assumes the ontologies necessary for operating exclusive reference, but they are not meant to apply to natural language. In the classification of words in natural language, Lowe makes a main distinction between "general" and "specialized" vocabulary, and the latter is subdivided into "mixed" (semi-technical) and "specialized" (technical) "mot technique" (Lowe, 2009, p. 3). However, a more accurate attempt to capture the relative nature of "technical terms" in natural language is found in the Dictionary of TechTerms, which specifies the level of technicality on a ten-point scale, which shows that only a tiny percentage of terms, mainly acronyms, are fully 
technical, i.e. they score ten out of ten (see TechTerms). The results obtained from the four approaches above emphasize the need to incorporate the ontological dimension recognized by Guarino (1992) and the arbitrariness endorsed by many linguists including Duan (2012). The current position is founded on actual examples, and it underlines the centrality of the epistemics of the term user and the semantic continuum of perceiving and using technical terms, two main features not found in Richards and Ogden's (1923) theory of reference.

The initiation, use and translation of technical terms are interrelated. In addition to the basic requirements of the term, two vital criteria have been suggested in the present work, namely the specificity and exclusivity of reference, and the epistemic status of the term user. In other words, the speaker needs to be using the term knowingly (different degrees of knowledge), intentionally and sincerely. To conclude, the following observations can sum up the present position:

1. Since exclusivity of reference depends on the relationship between the signifier and the signified, for a technical term to secure this condition, the designator, the symbol, should signify one referent, which takes one definite descriptor as its core. The definite descriptor identifies the knowledge base, the knowledge system and the knowledge level of the designated referent, an identification which is defined in a strict epistemic context of the relevant field or specialization (Gruber, 1991, p. 1). Processing interpretation in pre-formulation works from the above epistemic perspective to achieve successful retrieval of the definite descriptor and consequently the specific reference of the term. Translation in turn works back the way to specificity and then it aggregates the ontologies and epistemology of the term to identify the map that makes the exclusive reference to the referent in a new epistemic mapping to plot the referent in the TL and later in the TT. Having to carry out this interpretive processing, only the epistemologically empowered user/translator will use the term successfully.

2. The theory of sign as expounded in general linguistics (Lyons, 1968) cannot adequately account for the initiation and/or use of technical terms, since for each user the designation of the term spreads on a semantic continuum extending from the least technical, specific, to the most technical.

3. The user of the term, whether initiator or not, is central to the successful use of the term, because s/he determines the level of specific referent, i.e. knowledge content, and linguistic validity of a given occurrence of the term. Using technical terms develops with self-identification, through education and experience, leading to an epistemic continuum along which users spread from the layman to the full knower.

4. The symbol (linguistic sign), environmental context or sign situation to use Richards and Ogden's term (Richards \& Ogden, 1923, pp 48-56), and the specific referent of the term (object, event, or concept), are necessary criteria for a technical term. But they are not enough to lead to a meaningful reading (interpretation) if the user is not epistemically empowered knower of the designation of the term.

5. The evolution of Islamic terminology has matured over centuries of actual development of the contents, contexts and users, therefore it has accumulated situational and social residual that maintains a belief system for the conscious user, a system that cannot be shared outside the "believer's" circle, which adds to the complexity of the historical and epistemic load. It is a case in which the communal and individual interpretive paradigms fuse in the user of the term (Author, 2008).

6. The dynamics of reality generates new contexts and new contents relevant to the subject domain of the term, therefore resorting to old terminology, old words, to refer to and evoke new meanings will result in a conflict and will miss the specific referent of the current situation and the current use (Kuhn, 1962 \& 1982).

7. The translator of Islamic technical terms has to meet all the criteria required by the user, and in addition s/he has to carry out the process of semantic transportation of the content, to approximate the meaning to maintain the specificity of the SL term by achieving translational commensurability (Author, 2010) between the designator and designated, i.e. between the term and its referent.

8. Borrowing the SL terms, or translating by default, amounts to resigning the translator's prerogative and responsibility as a translator and user of the term in the TL. The translator needs to keep borrowing to an absolute minimum.

In the face of the complexity of using and translating Islamic terminology, the terminologist and the translator need to uphold quality in using and translating terms, and integrity in respecting specialization and subject domain. The user and translator of Islamic terminology has the knowledge and the opportunity to maintain the sensitive balance between the context and content of the term; that opportunity should not be missed.

\section{References}

Abu-Saleh, E. S. (2014). Medical Terminology. Amman, Dar Majdalawi Publishing.

Ali, A. Y. (1977/1934). The Holy Quran: Translation and Commentary. The United States, American Trust Publishers for the Muslim Students' Association.

Al-Jabri, M. A. [in Arabic] (1993). bunyat al aql al arabi (The Structure of Arabic Mind). Lebanon, Arabic Cultural Centre.

Al-Gabarti, A. (2009). 'ajā'ib al-āthār fi altrājem wal'akhbār (The Wonders of Remains in Biographies and Narrations). Cairo, Dar AL-kutub wa AL-Wathā'iq Al-Qawmiyya.

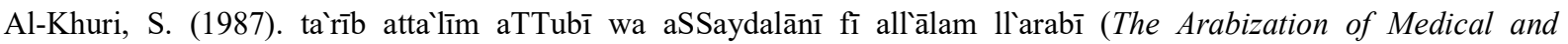
Pharmacological Instruction in the Arab World). Beirut, Dar Al-Rā' id Al-'arabī. 
Al-Mubarak, M. (1985). Allugatu alarabiya fì altalleem al'alì wa albaHth al ilmì (The Arabic Language in Higher Education and Academic Research). Damascus, Dar Al-Nafais.

Al-Sayadi, M. M. (1982). alta'rīb wadawrahu fì tad'̄̄m alwujūd al'arabī wa alwaHda al'arabiyya (Arabization and its Role in Supporting Arab Existence and Arab Unity). Beirut, Arab Unity Studies Center.

Al-Safi, O. A. A. [in Arabic] (1991). alqur'ān alkarīm: bid ìyatu tarjamati 'alfāzihi wa ma ānīh wa tafsīreh ...(The Holy Quran: The Heresy of Translating its Vocabulary, its Meanings and its interpretations ....). Beirut, Damascus and Amman, Islamic Office.

Author (forthcoming) Linguistic Interpretation: The Interpretive Frame and First Person Domain. Al-Ahsa, Saudi Arabia, Translation, Authorship and Publication Center, King Faisal University Press.

Author (2000). Aspects of the Language of Translation in the Translations of the Quran into European Languages, Damascus University Journal. Syria, Vol. 16, No 1, pp. 19-49.

Author (2001). The Place of Marracci's Latin Translation of The Holy Quran: A Linguistic Approach, Journal King Saud University, Languages and Translation. 13, pp. 57-74.

Author (2003a). The Evolution of Translation Culture: Translating the Holy Quran into French, Journal of King Saud University, Languages \& Translation. 15, pp. 21-48.

Author [in Arabic] (2003b). fuSūl fì alta'wīl wa lughatu altarjama (Episodes in Interpretation and the Language of Translation (Necessity, Convention, and Relative Stability in the Translation of Quranic Names into European Languages), Author and Al-Naser, S. J., Damascus, Syria: Dar Al-Hasad, pp.119-177.

Author (2008). From Necessity to Infinity: Interpretation in Language and Translation. London, Janus.

Author (2010). The Role of Micro Interpretation and Semantic Primitives in Translational Commensurability, KFU Scientific Journal, Vol. 11, 1, pp. 201-234.

Author (2012a). First Person Domain: Threshold Mental Lexicon and Arab Learners of English, Proceedings of the Second Symposium on English Language Teaching in KSA: Realities and Challenges: Research Papers. Riyadh, Saudi Arabia, 9-11 April, 2012, pp. 141-208.

Author (2012b). Textual Source and Assertion: Sale's Translation of the Holy Quran, Journal of King Suad University: Languages and Translation, 24, pp. 1-21.

Badawi, A. (No Date). Dirāsāt wa nuSūS fii alfalsafa ‘nda al'arab (Studies and Texts on Arabic Philosophy and Science). Lebanon, Arabic Studies and Publications.

Davidson, D. (2006 originally 1984). First Person Authority, in Davidson, D. 2006: The Essential Davidson. Oxford, Oxford University Press, pp. 242-250.

De Saussure, F. (2011, originally in French 1916). Course in General Linguistics. New York, Colombia University Press.

Duan, M. (2012). On the Arbitrary Nature of Linguistic Sing, Theory and Practice in Language Studies. Vol. 2, No. 1, pp. 54-59.

Fatma-Zaida (1861). L'Alkoran: Le Livre par Excellence, Lisbonne, Imprimerie de la Société Typographique FrancoPortugaise.

Frege, G. (1993 originally 1892). 'On Sense and Reference', in A. W. Moore (ed.) (1993): Meaning and Reference. Oxford, Oxford University Press, pp. 23-42.

Grice, H. P. (1967). Logic and Conversation, in Cole, P. and Morgan, J. L. (eds.): Syntax and Semantics: Vol. 3: Speech Acts. New York, Academic Press.

Guarino, N. (1992). Concepts, Attributes, and Arbitrary Relations: Some Linguistic and Ontological Criteria for Structuring Knowledge Bases, Data and Knowledge Engineering. 8 Issue 3, pp. 249-261. From http://dl.acm.org/citation.cfm?id=144362

Kolb, D. (1984). Experiential Learning: Experience as the Source of Learning and Development. Englewood Cliffs, NJ, Prentice-Hall, Inc.

Kripke, S. A. (1972). Naming and Necessity. Cambridge, Massachusetts, Harvard University Press.

Kuhn, T. (1982). Commensurability, Comparability, Communicability, PSA: Proceeding of the Biennial Meeting of the Philosophy of Science Association. 2, PP. 669-688.

Kuhn, T. (1962). The Structure of Scientific Evolutions. Chicago, The University of Chicago Press.

Idara Dawat (1997). Qadiani Changes to the Translation of the Holy Quran. From http://irshad.org/ exposed/translation.php.

Irving, T. B., Ahmed, K. \& Ahsan, M. M. (1979). The Qur'an: Basic Teaching. London, The Islamic Foundation.

Irving, T. B. (1992). The Noble Qur'an: Arabic Text and English Translation. Brattleboro, Vermont USA, Amana Books.

Lowe, I (2009). A Question of Terminology. From http://www.scientificlanguage.com/esp/terminology.pdf 
Lyons, J. (1968). Introduction to Theoretical Linguistics. Cambridge, Cambridge University Press.

Mawada, M. (1986). Harakat altarjama fī tūnis wa' abraz maZāhirahā fĩ al'adab (Translation Movement in Tunisia and its Main Characteristic in Literature). Tripoli (Libya) and Tunis (Tunisia), Al-Dar Al’arabiyya lilkitāb,

Miller, J. W. (1980). The Definition of the Thing: With Some Notes on Language. New York and London, W. W. Norton and Company.

Numan A. (1981). Al-ta Yīb bayna al-mabda' wa altaTbīq (Arabization Between Principles and Application). Algiers, The National Company for Publication and Distribution.

Plato (Allan Bloom Translator) (1988). The Republic of Plato. USA, BasicBooks, HaperCollins Publishers. From http://www.inp.uw.edu.pl/mdsie/Political_Thought/Plato-Republic.pdf.

Pym, A. (1994). Twelfth-Century Toledo and Strategies of Literalist Trojan Horse, Target. The Netherlands, 6, 1, pp. 43-66.

Pym, A. (1995). Translatio Disputatio, and the First Latin Qur'an. From http://usuaris.tinet.cat/apym/online/translation/1995_Qur'an_preprint.pdf

Searle, J. (1969). Speech Acts. Cambridge, Cambridge University Press.

Sperber, D. \& Wilson, D. (1995). Relevance: Communication and Cognition. NJ (USA), Wiley-Blackwell.

Richards, I. A., \& Ogden, C. K. (1989/1923). The Meaning of Meaning. USA, Harcourt Jovanovich, Inc.

Rosenberge, J. F. (1994). Beyond Formalism: Naming and Necessity for Human Beings. Philadelphia, Temple University Press.

Ross, E. B. (1979). Introduction, in Sale, in Sale, G. (translator): The Korân: Translated into English from The Original Arabic. London, Frederick Warne.

Russell, B. (1962). 'On denoting', Mind. 14, pp. 479-93.

Russell, B. (1993) (originally 1919). 'Descriptions', in A. W. Moore (Ed.) (1993): Meaning and Reference. Oxford, Oxford University Press, pp. 46-55.

Saleh, M. I. (2011). Dictionary of Islamic Words and Expressions. Al-Riyadh, Darussalam.

Searle, J. R. (1975). Indirect Speech Acts, in Cole, P. and Morgan, J. L. (eds.): Syntax and Semantics. Vol. 3, pp. 59-82.

Stanford Encycllopedia of Philosophy (2006). Rigid Designators. Retrieved from http://plato.stanford.edu/entries/ rigiddesignators/.

Tajer, J. (1945). Harakat altarjama bimaSr khilāl alqarn altāsi' 'ashar (Translation Movement in Egypt in the Nineteenth Century). Cairo, Dar Alma`ārif.

Technical Terms. From http://techterms.com/

Wellisch, H. H. (1981). Ebla: The World Oldest Library. The Journal of Library History. Vol. 16, No. 3, pp. 488-500.

Retrieved from http://rbedrosian.com/Libraries/Libraries_Ebla.pdf, http:/www.jstor.org/page/info/about/ policies/terms.jsp.

\section{Notes:}

i See Abu-Saleh's book (2014), Medical Terminology, which according to the preface is being taught at a university in Jordan.

ii Looked at from a wider perspective, Arabization has undergone surges and setbacks: a slow progress is reported from Algeria (Numan, 1981), a relative success is achieved in Syria where Damascus University has been using Arabic for all its instruction for more than sixty years (Al-Mubarak 1985 \& Al-Khuri, 1987), and a more pigeonholed picture is attested in the Arabian Gulf countries where Arabic is used for humanities and religious studies and English for Science, technology and Medicine.

iii One of the earliest Muslims to translate the Quran into a European language was Fatma-Zaida whose French translation was published in (1861), in Lisbon.

iv Marracci's Refutati AlQurani was doomed to fail as a refutation of the Muslim faith and creed, but his translation gave a complete accurate parallel Latin, which has influenced almost all Europe translations after him (see Author, 2000, 2001, 2003, 2008, 1012b and forthcoming). 